\title{
UNCONVENTIONAL DOUBLE-LEVEL STRUCTURAL SYSTEM FOR UNDER-DECK CABLE-STAYED BRIDGES
}

\author{
Ieva Misiūnaité ${ }^{1}$, Alfonsas Daniūnas ${ }^{2}$, Algirdas Juozapaitis ${ }^{3}$ \\ Faculty of Civil Engineering, Vilnius Gediminas Technical University, \\ Saulètekio al. 11, LT-10223 Vilnius, Lithuania \\ E-mails: ${ }^{1}$ ieva.misiunaite@vgtu.lt (correspondingauthor); ${ }^{2}$ alfonsas.daniunas@vgtu.lt; \\ algirdas.juozapaitis@vgtu.lt \\ Received 02 Jan. 2011; accepted 10 Feb. 2012
}

\begin{abstract}
This paper presents a new morphology of a cable-staying system for an under-deck cable-stayed bridge. The computational method proposed in the paper has been derived for a one-strut conventional cable staying system and applied for an unconventional double-level cable-staying system. The paper describes an algorithm for the correct implementation of the interaction between the cable-staying system and the deck. The numerical examples demonstrate that the proposed computational method based on a non-linear analysis of a simply supported and additionally restrained beamcolumn can be used for obtaining deformation response to the considered structure. An analysis of the same problem using finite element (FE) software ANSYS was carried out to present the accuracy of the proposed method. The paper also demonstrates comparison analysis between the conventional and unconventional structural schemes for the under-deck cable-stayed bridge under symmetric and asymmetric loading.
\end{abstract}

Keywords: under-deck cable-stayed bridge, double-level cable-staying system, non-linear analysis, computational method, beam-column, elastic restraint, structural response.

\section{Introduction}

Recently, the form-finding of bridge design and the analysis of structural behaviour have been highly considered. The development of new forms encouraged the implementation of innovative steel and reinforced concrete bridges (Troyano 2003; Virlogeux 1999; Nakamura et al. 2002, 2009). Subsequently, there are a significant number of the new forms of footbridges (Fib 2005) among which suspension and cable-stayed bridges (Strasky 2005) appear as highly efficient. Form-finding is an incessant process causing continuity in bridge design applying it for innovative bridges (Tanaka et al. 2002; RohdeBabarigos et al. 2010; Juozapaitis et al. 2006, 2010; Sandovič et al. 2011).

A number of bridges not falling into the conventional type of cable-stayed bridges with highly innovative morphology, namely under-deck cable-stayed bridges, have been built (Ruiz-Teran, Aparicio 2008, 2010). These bridges rather than the classic cable-stayed ones have the cable-staying system placed below the deck.

Very few studies have been conducted with regard to unconventional cable-stayed bridges. Some of those are based on experimental tests performed in connection with attempts to increase the eccentricity of active reinforcements in the beams having external prestressing (Menn, Gauvreau 1990; Umezu et al. 1998; Aravinthan et al. 2005; Zhang, Fu 2009). Other authors deal with these structures as new structural types maintaining their own identity (Laffanchi, Marti 1999; Muttoni 2002; Park et al. 2010) or an innovative structural system for roof structures (Juozapaitis, Kvedaras 1998; Xue, Liu 2009). Muttoni (2002) identifies the influence of the morphology of the structure and the number of struts on reducing bending moments in the deck due to live load compared with that for a bridge without stay cables. Ruiz-Teran and Aparicio (2007a, 2010) presents the state of art and parameters governing the response of under-deck cablestayed bridges. There is a possibility of applying the control of passive behaviour described by Michalopoulos et al. (2005).

The paper presents an unconventional structural scheme for the under-deck cable-stayed bridge - a double-level cable-staying system - introduced by the authors of the paper. A parametric analysis of a new structural system requires the development of governing equations that can be obtained proposing a computational method based on a structural response mechanism of a single span under-deck cable-stayed bridge supported by one strut. The paper also describes the algorithm for applying the proposed method to the under-deck cable-stayed bridge with the double-level cable-staying system. The example shows that governing equations derived using the computational method can be used for obtaining the deformation response of the considered structure. Subsequently, a comparative analysis of the under-deck cable-stayed bridge with conventional and unconventional cable- staying systems has been performed. 


\section{The under-deck cable-stayed bridge with the double-level cable-staying system}

Stay cables in conventional under-deck cable-stayed bridges have a polygonal layout by deviating them applying one or several struts. When using multiple struts, the cable-staying system gains a parabolic layout. This section describes the unconventional layout of the cablestaying system using the previously mentioned layout of one strut. The application of the proposed structural scheme for the under-deck cable-stayed bridge requires the repeated usage of the cable-staying system. Fig. 1 shows possible variations of such cable-staying system, namely the double-level cable-staying system.

The proposed structural scheme is an effective combination of three conventional one strut cable-staying systems and gains a double level layout. The morphology of the considered cable-staying system is formed using one conventional system for the first and two for the second level respectively. The first level stay-cables are self anchored to the deck at the abutments and deviated by one strut at the midspan. The semi-continuous structural scheme is formed assuming hinge connection at the place of the strut. Thus, the subdivision of the span of the deck is made, and two independent spans of a half of the whole length of the span are designed. By applying the one strut cable-staying system to both independent spans, the second level of new morphology is developed. The second level stay-cables are self-anchored to the deck at the abutments and midspan of the deck and deviated by one strut at the $1 / 4^{\text {th }}$ and $3 / 4^{\text {th }}$ of the span respectively.

For designing stay cables, the standard tension members can be used (Kathage, Misiek 2012), and the conception of semi-rigid joints can be applied (Daniūnas et al. 2008, 2010).

a)

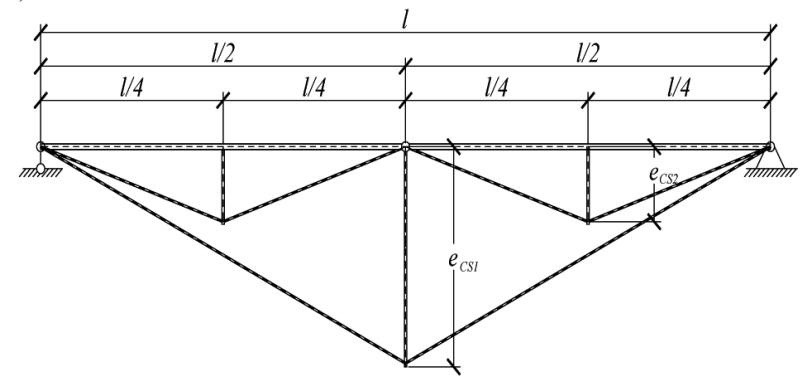

b)

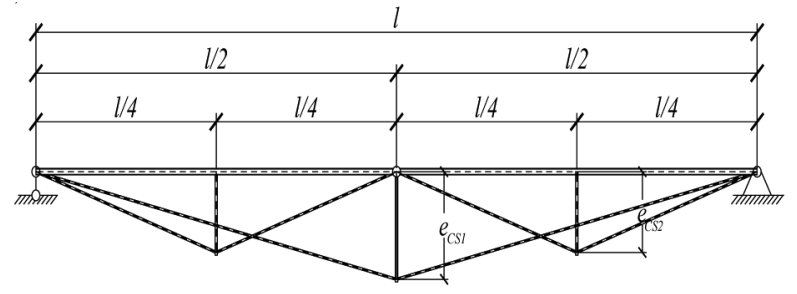

Fig. 1. Structural schemes for the under-deck cable-stayed bridge with the a) framing first level cable-staying system; b) passing first level-cable staying system
Fig. 1 shows the development of two different morphologies that can be obtained with reference to different eccentricity $e_{C S}$ of the first level cable-staying system with respect to the length of the strut. The morphology presented in Fig. 1a and Fig. 1b describes first level cable-staying system framing and passing second level cablestaying system respectively.

The analysis of the structural behaviour of the considered bridge develops the non-linear buckling problem (Ruiz-Teran, Aparicio 2011; Bjorhovde 2010; Kala et al. 2010). For reaching a solution to the encountered problem, the computational method has been proposed to derive general equations for the structural response of such type of the bridge.

\section{Description of the proposed method}

For a structural analysis of the proposed semi-continuous structural scheme, a response mechanism in the underdeck cable-stayed bridge has to be described.

There are two response mechanisms in the underdeck cable-stayed bridge considering the action of vertical loads: axial response (tension of stay cables and compression of the deck and struts) and flexural response (bending of the deck) (Ruiz-Teran, Aparicio 2007b). Fig. 2 describes these mechanisms of structural response in the under-deck cable-stayed bridge with one strut at the midspan under the action of uniform distributed vertical load. The same structural response can be found in a simply supported continuous beam additionally restrained in the centre. Such structural members are termed an additionally restrained beam-column.

Axial compression and restraint stiffness are related to the structural response of the cable-staying system. For a correct solution, the structural response of the cablestaying system has to be analyzed following an appropriate procedure and correctly implemented in the calculation model of the additionally restrained beam-column. Fig. 2 shows the calculation model of such element.

When considering the interaction between the cablestaying system and the deck, the axial response of the cable-staying system can be sub-divided into horizontal and vertical components respectively and implemented into the calculation model. The horizontal component $H_{t}$ of axial force in cable-staying system can be introduced to the beam-column as compression load $N_{c}$ and the vertical can be found as compression force in strut $F_{C S v}$. The strut at the midspan of the deck prevents it from lateral deflection and can be implemented as elastic restraint in the calculation model with appropriate stiffness $\alpha$. By applying lateral restraint, the deflection of the member is restricted to greater or lesser extent $\delta$. The deflection of the structural element due to external loading develops restoring force $F_{v}$ at the restraint related to an axial response of strut $F_{C S v}$. Finally, the analysis procedure of the developed calculation model is based upon the solution to appropriate differential equations. 
a)

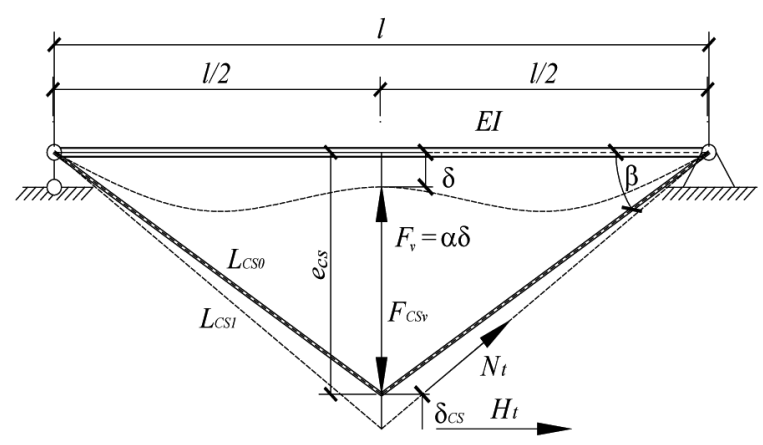

b)

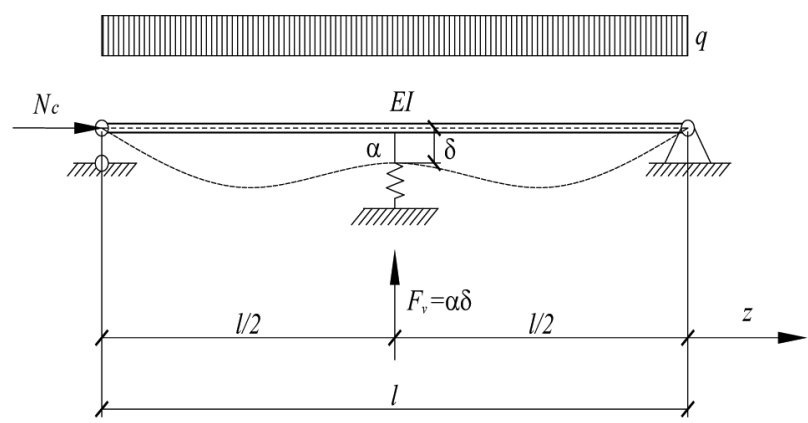

Fig. 2. The analysis of the under-deck cable-stayed bridge with the cable staying system with one strut: a) the interaction between the cable-staying system and the deck, b) calculation model of the simply supported additionally restrained continuous beam simultaneously subjected to axial compression and distributed vertical load

\subsection{General equations}

When considering the calculation model of the simply supported beam-column with the central elastic restraint shown in Fig. 2b, to analyse the structural response of the under-deck cable-stayed bridge, general equations can be derived. The beam-column element of length $l$ and constant flexural rigidity $E I$ is laterally restraint at the point of $l / 2$. It is assumed that when compression load $N_{c}$ and distributed force $q$ are applied to the member, it deforms, as shown in Fig. 2a, with central deflection $\delta$, and the restraint exerts restoring force $F_{v}$. The equilibrium equation for the deflected shape is

$$
E I \frac{d^{4} v}{d z^{4}}+N_{c} \frac{d^{2} v}{d z^{2}}=q(z) .
$$

The continuity of loading and boundary conditions $v(0, l)=v^{\prime \prime}(0, l)=0, v(l / 2)=\delta, v^{\prime}(l / 2)=0$ for the parts of the beam-column to the left $0 \leq z \leq l / 2$ and right $l / 2 \leq z \leq l$ of the central restraint enables to consider the problem for a half of the structural element. By combining a general solution to Eq. (1) with boundary conditions and introducing $k l=l \sqrt{\frac{N_{c}}{E I}}$, deflection is obtained

$$
\begin{aligned}
v= & \frac{1}{N_{c}}\left[\frac{1}{2} F_{v} l\left(\frac{z}{l}-\frac{\sin k z}{k l \cos \frac{k l}{2}}\right)+\frac{q l^{2}}{(k l)^{2}}\left(\operatorname{tg} \frac{k l}{2} \sin k z+\right.\right. \\
& \left.\cos k z-1)-q z\left(\frac{l}{2}-\frac{z}{2}\right)\right],
\end{aligned}
$$

where $F_{v}$ is restoring force at the restraint and can be obtained by solving $F_{v}=E I v^{\prime \prime \prime}$ as

$$
F_{v}=\frac{q l}{k l} \frac{\left(1+(k l)^{2} / 2-1 / \cos k l\right)}{(k l-t g k l)}+N_{c} \frac{\delta}{l} \frac{k l}{(k l-t g k l)} .
$$

According to $M=-E I v^{\prime \prime}$, the bending moment is equal to

$$
M(z)=\frac{q l^{2}}{(k l)^{2}}\left(\operatorname{tg} \frac{k l}{2} \sin k z+\cos k z-1\right)-\frac{F_{v} l}{2 k l} \frac{\sin k z}{\cos \frac{k l}{2}} .
$$

It should be noted that the sum of two terms in Eq. (3) represents the interaction between flexural and axial response.

\subsection{Determination of axial force}

The interaction between the deck and the cable-staying system under distributed vertical load presented in Fig. 2a results in the axial force in the deck. By applying the iteration process to an axial response of the cable-staying system developed by non-linear analysis, axial force can be obtained as follows

$$
N_{c}=\frac{F_{v C S} l}{4\left(e_{C S}+\delta_{C S}\right)} .
$$

For the first iteration, the vertical component of axial force in cable-staying system $F_{v C S}$ may be assumed to be constant and equal to restoring force at restraint $F_{v}$. Accordingly, taking into account Eq. (3), restoring force may be obtained as one of boundary solutions when central deflection $\delta$ approaches zero.

The deflection of cable-staying system $\delta_{C S}$ can be found by constitutive equations

$$
L_{C S, 1}=L_{C S, 0}+\Delta L_{C S},
$$

where $L_{C S, 0}$ is the initial length of stay cables as shown, in Fig. 2a

$$
L_{C S, 0}=2 \sqrt{e_{C S}^{2}+0.25 l^{2}},
$$

$L_{C S, 1}$ is the length of stay cables in the deflected shape

$$
L_{C S, 1}=2 \sqrt{\left(e_{C S}+\delta_{S C}\right)^{2}+0.25 l^{2}},
$$

and $\Delta L_{C S}$ is an elastic elongation of stay cables

$$
\Delta L_{C S}=\frac{H_{t} l}{E_{C S} A_{C S} \cos ^{2} \beta},
$$


where $\beta$ is the angle between stay cables and the deck shown in Fig. 2a; $E_{C S}$ and $A_{C S}$ are the modulus of elasticity and the cross-section of stay cables respectively.

Furthermore, the deflection of the cable-staying system may be obtained approximately by

$$
\delta_{C S}=\frac{F_{v C S} l^{3}}{16 E_{C S} A_{C S} e_{C S}{ }^{2}\left(1+F_{v C S} l^{3} / 16 E_{C S} A_{C S} e_{C S}{ }^{3}\right)} \text {. }
$$

At the end of the iteration, a convergence check of restoring force $F_{v}$ and the vertical component of axial force in cable-staying system $F_{v C S}$ is carried out

$$
\left|F_{v C S}\right|-\left|F_{v}\right| \leq \varepsilon \text {. }
$$

Parameter $\varepsilon$ depends on acceptable tolerance, i.e. the desired accuracy of the iteration process.

\subsection{Numerical example}

To test the accuracy of the proposed computational method, numerical analysis was carried out. The calculation model of the under-deck cable-stayed bridge with the one strut cable-staying system shown in Fig. $2 b$ was used. In the calculation model, the span of the bridge assumed of $18 \mathrm{~m}(l=18)$ and the properties of the cross-section were taken as follows: $A=14282 \mathrm{~mm}^{2}, \quad I=0.242 \mathrm{E}+9 \mathrm{~mm}^{4}$, $h=300 \mathrm{~mm}, E=210000 \mathrm{~N} / \mathrm{mm}^{2}$. The cable-staying system of two stays, each with a cross-section of $A_{C S}=7848 \mathrm{~mm}^{2}$ and the modulus of elasticity $E_{C S}=210000 \mathrm{~N} / \mathrm{mm}^{2}$ was self-anchored into the deck and deflected by one strut at the midspan subdividing it into two equal parts. The strut was $3 \mathrm{~m}$ long; thus, the eccentricity of the cable-staying system was $1 / 12^{\text {th }}$ of the span $\left(e_{C S}=3 \mathrm{~m}\right)$. The cross-section of the strut was $A_{S}=5184 \mathrm{~mm}^{2}$, the modulus of elasticity $E_{S}=210000 \mathrm{~N} / \mathrm{mm}^{2}$ and had a pin connection with the deck. Subsequently, the same structural scheme was used for solving the problem with the nonlinear solver of finite element software ANSYS.

Table 1 shows the numerical results of the flexural response of the deck by means of the bending moment and deflection at the point of $z=9 \mathrm{~m}$. Furthermore, restoring force at the restraint was calculated using general equations of the proposed computational method. In para- llel with parametric analysis, the results of the same key aspects were obtained by running the non-linear solver of FE software ANSYS. The results of ANSYS give the axial response of the strut instead of restoring force obtained by combining general equations and the calculation model. Although, it can be seen that differences are less than one percent, thus, restoring force in the calculation model approaches axial compression in the structural scheme. The last column in Table 1 shows that all differences are acceptable to represent the computational method to be accurate and relevant.

\section{The application of the proposed method for the double-level cable-staying system}

For the application of the proposed computational method of the one strut cable-staying system to the structural scheme with the double-level cable-staying system, the following algorithm can be used.

- The whole structural scheme is sub-divided into three individual structural schemes. One of those incorporates the geometry of the first and two others of the second-level cable-staying system respectively. According to the structural schemes, two calculation models of an additionally restrained beam column have to be used.

- When using general equations for the non-linear analysis of the considered structure, the first and the second calculation models are used separately. The interaction must be assessed with reference to the iteration process.

- Compression force implemented in the calculation model to obtain the structural response of the whole structure must be calculated following a two step procedure. First, non-liner analysis is performed combining the first calculation model of the additionally restrained beam-column and axial compression obtained performing the first level-cable system analysis. Then, the obtained axial force is amplified analysing the second level cable-staying system and the convergence of axial forces.

- The iteration process has to be repeatedly carried out for both the accuracy of axial force and restrained deflection and implemented into the second calculation model. Then, general equations can be used for obtaining the key parameters.

\begin{tabular}{|c|c|c|c|}
\hline & Proposed computational method & $\begin{array}{c}\text { FE model with } \\
\text { ANSYS }\end{array}$ & Difference \\
\hline \multicolumn{4}{|l|}{ Bending moments in the deck } \\
\hline Maximum $(\mathrm{kNm})$ & -185.8 & -186.9 & $0.60 \%$ \\
\hline Minimum $(\mathrm{kNm})$ & 139.7 & 140.9 & $0.87 \%$ \\
\hline \multicolumn{4}{|l|}{ Deflection } \\
\hline Maximum (mm) & 26.98 & 27.07 & $0.35 \%$ \\
\hline \multicolumn{4}{|l|}{ Axial response in the strut } \\
\hline Compression load $(\mathrm{kN})$ & 225.4 & 226.1 & $0.27 \%$ \\
\hline
\end{tabular}

Table 1. The results of the numerical example 


\subsection{Numerical example}

This section runs a numerical example of the under-deck cable-stayed bridge with the unconventional cable staying system. The problem was solved using both the computational method and commercial software ANSYS based on a non-linear algorithm.

Consider the structural scheme and geometrical parameters used for the numerical example provided in Section 3.3. According to the layout of the cable-staying system shown in Fig. 1a, two structural schemes were used for the morphology of the second-level cablestaying system. When implementing two structural schemes with one strut in the whole structure, the span of the bridge gets the length of $36 \mathrm{~m}$.

The stay cables of the first level cable-staying system had the eccentricity of $4 \mathrm{~m}$, which is the $1 / 9^{\text {th }}$ of the span. The numerical value of a cross section of stay cables has been taken the same as the one for the second level stay cables and is presented in Section 3.3.

Both symmetric and asymmetric load cases were considered to obtain the flexural response of the deck. In case of symmetric loading, uniform vertical force $q=20 \mathrm{kN} / \mathrm{m}$ was applied to the whole structure. When considering the case of asymmetric loading, distributed vertical force $q=20 \mathrm{kN} / \mathrm{m}$ acted on a half of the span and $q=10 \mathrm{kN} / \mathrm{m}$ was applied to the other one.

Table 2 shows the extreme values of hogging and sagging bending moments and the maximum values of the deflection in the deck. For the case of symmetric loading, the deformation response of the deck is presented in the first column in Table 2 . When applying asymmetric load, the deformation response of the deck is the combination of the results given in the first and second columns in Table 2 respectively.

Differences declare the accuracy of the computational method comparing to the non-linear solver of FE software ANSYS. According to differences less than one percent, the computational method can be efficiently applied to the structural analysis of the under-deck cablestayed bridge with the double-level cable-staying system both for symmetric and asymmetric loading.

\section{Comparison of conventional and unconventional cable-staying systems}

To highlight the stability of the proposed morphology, structural schemes for the under-deck cable-stayed bridge with double-level and multiple struts cable-staying systems were analysed using FE software ANSYS. For the structural scheme of the under-deck cable-stayed bridge with the double-level cable-staying system, geometrical parameters were taken as described in Section 4.1. Alternatively, the structural scheme of the length of $36 \mathrm{~m}$ span bridge with the eccentricity of a cable-staying system of $4 \mathrm{~m}$, which is the $1 / 9^{\text {th }}$ of the span was analysed. The structural scheme with multiple struts had the parabolic layout of the cable-staying system designed of 7 struts and previously described eccentricity at the midspan. Alternative structural schemes are shown in Fig. 3.

The cross-section parameters of the structural elements of the cable-staying system and the deck of the bridge with the multiple struts cable-staying system were taken as described in Section 3.3.

In case of a permanent state, superimposed dead load $g=10 \mathrm{kN} / \mathrm{m}$ was applied. According to possible live load models for footbridge design, the case of symmetric and asymmetric loading was considered and configurations of load $q=10 \mathrm{kN} / \mathrm{m}$ were used as shown in Fig. 3.

The limit value of maximum deviation of the structure to satisfy serviceability limit state and aesthetic requirements was set to $90 \mathrm{~mm}$.

The deformation response of alternative structural schemes was obtained performing the non-linear analysis of the structure to compare and contrast the selected schemes. The numerical values of extreme bending moments in the deck and a deformed shape of both analyzed structural schemes under symmetric and asymmetric loading are presented in Fig. 3.

In case of symmetric loading, the extreme bending moments in the under-deck cable-stayed bridge with conventional cable-staying system are less than those in the bridge with unconventional cable-staying system. Thus, the conventional cable-staying system becomes more efficient. According to a greater number of struts, the subdivision of the deck increases. An increase in the subdivision of the span localizes bending moments and decreases the flexural response of the deck.

Table 2. The results of the numerical example

\begin{tabular}{|c|c|c|c|c|c|c|}
\hline \multicolumn{7}{|c|}{ Asymmetric loading } \\
\hline & $\begin{array}{c}\text { Proposed } \\
\text { computational } \\
\text { method }\end{array}$ & $\begin{array}{l}\text { FE model } \\
\text { with } \\
\text { ANSYS }\end{array}$ & Difference & $\begin{array}{c}\text { Proposed } \\
\text { computational } \\
\text { method }\end{array}$ & $\begin{array}{l}\text { FE model } \\
\text { with } \\
\text { ANSYS }\end{array}$ & Difference \\
\hline & \multicolumn{3}{|c|}{ Multispan with applied load: $q=20 \mathrm{kN} / \mathrm{m}$} & \multicolumn{3}{|c|}{ Multispan with applied load: $q=10 \mathrm{kN} / \mathrm{m}$} \\
\hline \multicolumn{7}{|l|}{ Bending moments in the deck } \\
\hline Maximum $(\mathrm{kNm})$ & -186.9 & -186.7 & $-0.11 \%$ & -87.55 & -87.53 & $-0.03 \%$ \\
\hline Minimum $(\mathrm{kNm})$ & 136.7 & 136.6 & $-0.06 \%$ & 69.30 & 69.28 & $-0.03 \%$ \\
\hline \multicolumn{7}{|l|}{ Displacement } \\
\hline Maximum (mm) & 64.6 & 64.6 & $-0.01 \%$ & 75.55 & 75.53 & $-0.08 \%$ \\
\hline
\end{tabular}


a)
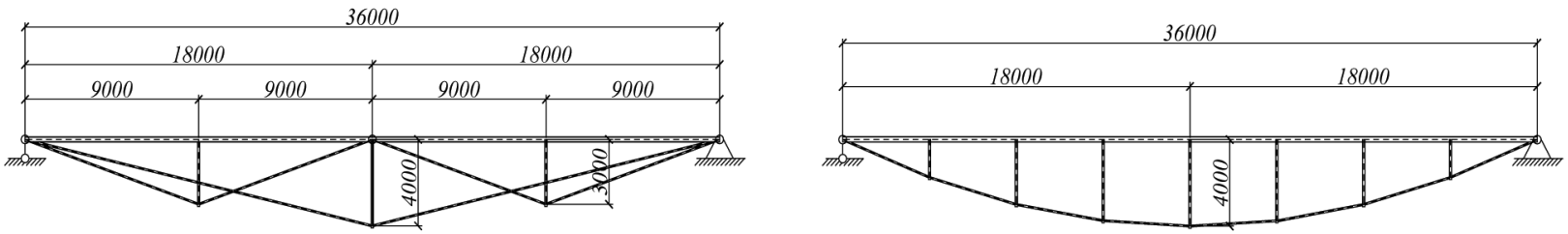

b)
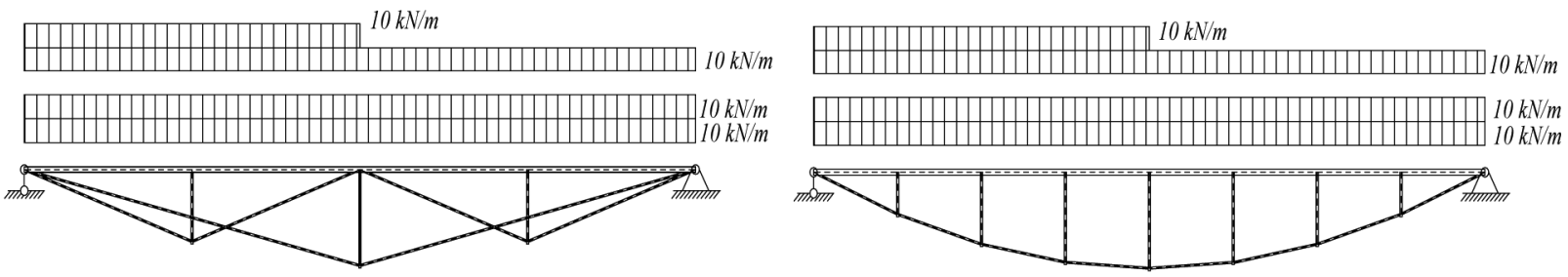

c)
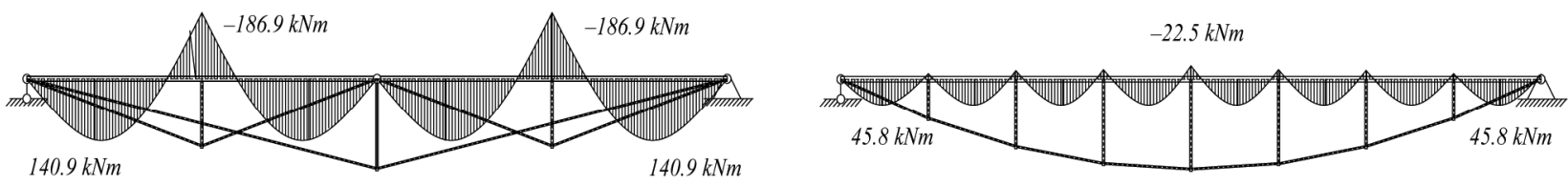

d)
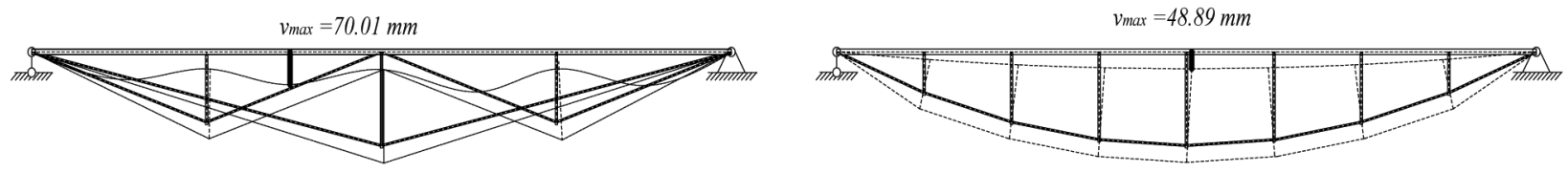

e)
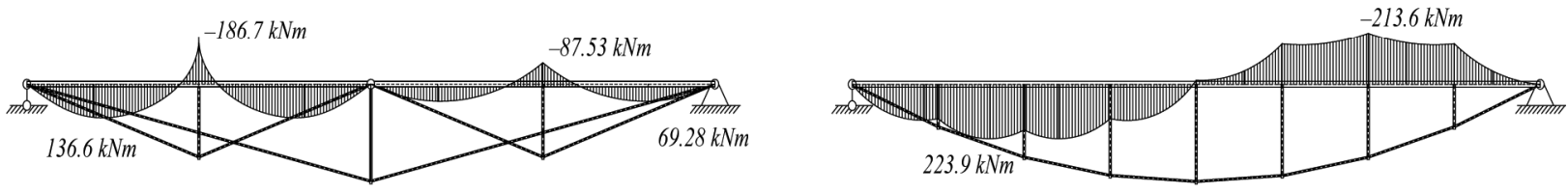

f)
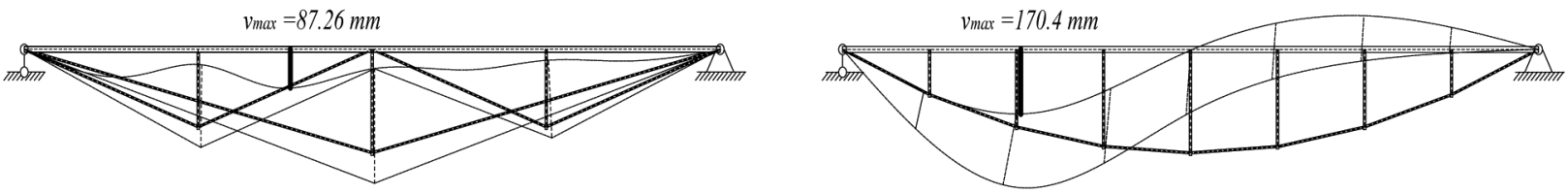

Fig. 3. The representation of the numerical analysis of alternative structural schemes for the under-deck cable-stayed bridge: a) geometrical parameters and structural schemes; b) application of symmetric and assymmetric loading; c) distribution of bending moments under symmetric loading; d) deflection shape of the structures under symmetric loading; e) distribution of bending moments under assymmetric loading; f) deflection shape of the structures under asymmetric loading

In case of asymmetric loading, the unconventional double-level cable-staying system causes less flexural response of the deck by means of lower extreme values of bending moments compared to the conventional bridge.

A comparison of deformations of alternative schemes points out that the double-level cable-staying system is more stable than the multiple struts cable-staying system. The aspect of stability has great importance for designing bridge structures, which indicates that the structural scheme with multiple struts is sensitive to asymmetric loading and deflects in the asymmetric shape. Furthermore, deflection exceeds the limit value to satisfy requirements for serviceability limit state. Thus, the flexural rigidity of the deck has to be increased, and the moment of inertia set to $I=0.559 E+9 \mathrm{~mm}^{4}$ to get the deflection of $86.54 \mathrm{~mm}$ which fits into the established limits.

Economy was not the key aspect of comparison analysis. However, the flexural rigidity of the steel beam used for designing the deck in case of the multiple struts structural scheme has to be increased in order to fit the limit value of deflection, and that causes an increase in the cross-section. The growth of the cross-section of the beam causes an increase in active steel and a decrease in economic efficiency. 


\section{Conclusions}

The paper presents the new morphology of the cablestaying system for the under-deck cable-stayed bridge termed the double-level cable-staying system. Fig. 1 shows possible variations in the layout of the unconventional cable-staying system according to the eccentricity of the first level.

The paper describes the structural response mechanism of the under-deck cable stayed bridge with the one strut cable-staying system. Fig. 2 shows the interaction between the cable-staying system and the deck. The nonlinear behaviour of the cable-staying system causes the non-linear problem for the analysis of the considered bridge. To solve the problem, Fig. 2 shows a calculation model of an additionally restrained beam-column element. A combination of the calculation model and the iteration process proposes the computational method for the structural response of the under-deck cable-stayed bridge with the one strut cable-staying system. The method is based on appropriate differential equations. The usage of the computational method derives general equations for determining the structural response of the bridge. The application of the equations given in Section 3.1 provides a possibility of obtaining the deformation response of the deck by means of the bending moments and deflections of the deck as well as the axial response of the strut. Numerical analysis was carried out to compare the results obtained using the proposed method and the non-linear solver of FE software ANSYS. Table 1 presents that differences are in the acceptable range and the proposed method can be efficiently applied for the considered bridge structure.

The application of the proposed calculation method to the non-linear analysis of the structural scheme for the unconventional under-deck cable-stayed bridge is described combining three independent structural schemes of the one strut cable-staying system. Section 4 has described the algorithm for an appropriate design of the underdeck cable-stayed bridge with the double-level cablestaying system. Numerical examples were run to present application possibilities under symmetric and asymmetric loading of the bridge. The analysis of the considered problem was performed using the non-linear solver of ANSYS, and the differences are given in Table 2.

Finally, a comparative analysis of conventional and unconventional under-deck cable-stayed bridges shown in Fig. 3 was performed. In case of asymmetric loading, analysis shows that the unconventional cable-staying system is more stable than the conventional one with multiple struts. Stability is exceptionally important for designing bridges.

\section{Acknowledgement}

The first author of the paper expresses her gratitude to Prof. R. K Rasmussen (The University of Sydney) for supervising performing studies with regard to this paper.

\section{References}

Aravinthan, T.; Witchukreangkrai, E.; Mutsuyoshi, H. 2005. Flexural behavior of two-span continuous prestressed concrete girders with highly eccentric external tendons, ACI Structural Journal 102(3): 402-411.

Bjorhovde, R. 2010. Evolution and State-of-The-Art of Column Stability Criteria, Journal of Civil Engineering and Management 16(2): 159-165.

http://dx.doi.org/10.3846/jcem.2010.16

Daniūnas, A.; Urbonas, K. 2008. Analysis of the steel frames with the semi-rigid beam-to-beam and beam-to-column knee joints under bending and a xial forces, Engineering Structures 30(11): 3114-3118.

http://dx.doi.org/10.1016/j.engstruct.2008.04.027

Daniūnas, A.; Urbonas, K. 2010. Influence of the semi-rigid bolted steel joints on the frame behaviour, Journal of Civil Engineering and Management 16 (2): 237-241. http://dx.doi.org/10.3846/jcem.2010.27

FIB (International federation for structural concrete) bulletin 32, 2005. Guidelines for the design of footbridges. Sprintdigital-druck, Stuttgart. $154 \mathrm{p}$.

Juozapaitis, A.; Kvedaras, A. K. 1999. Innovative structural systems of steel roofs, Journal of Constructional Steel Research 49(2): 213-221.

http://dx.doi.org/10.1016/S0143-974X(98)00219-3

Juozapaitis, A.; Vainiunas, P.; Kaklauskas, G. 2006. A new structural system of a suspension pedestrian bridge, Journal of Constructional Steel Research 62(12): 12571263. http://dx.doi.org/10.1016/j.jcsr.2006.04.023

Juozapaitis, A.; Idnurm, S.; Kaklauskas, G.; Idnurm, J.; Gribniak, V. 2010. Non-Linear Analysis of Suspension Bridges with Flexible and Rigid Cables, Journal of Civil Engineering and Management 16(1): 149-154. http://dx.doi.org/10.3846/jcem.2010.14

Kala, Z.; Puklický, L.; Omishore, A.; Karmazínová, M.; Melcher, J. 2010. Stability Problems of Steel-Concrete Members Composed of High-Strength Materials, Journal of Civil Engineering and Management 16(3): 352-362. http://dx.doi.org/10.3846/jcem.2010.40

Kathage, K.; Misiek, Th. 2012. Bemessung und Konstruktion von Zuggliedern nach DIN EN 1993-1-11, Stahlbau 81(4): 324-331. http://dx.doi.org/10.1002/stab.201201542

Laffanchi, M.; Marti, P. 1999. Zur Konzeption gekrümmter Bracken. Institut fur Baustik und Konstruktion (IBK), ETH, Zürich, Switzerland.

Menn, C.; Gauvreau, P. 1990. Externally prestressed concrete slab bridges: model test results, in External Prestressing in Bridges, ACI Special Publication SP-120. American Concrete Institute (ACI), Detroit, Mich, 289-304.

Michalopoulos, A.; Nikolaidis, Th.; Stavroulakis, G.; Baniotopoulos, C. 2005. Passive control of bridges: The double net method, Engineering Structures 27(13): 18351842. http://dx.doi.org/10.1016/j.engstruct.2005.06.006

Muttoni, A. 2002. Brücken mit Stahlunterspannung, Stahlbau 71(8): 592-597.

Nakamura, S.; Momiyama, Y.; Hosaka, T.; Homma, K. 2002. New technologies of steel/concrete composite bridges, Journal of Constructional Steel Research 58(1): 99-130. http://dx.doi.org/10.1016/S0143-974X(01)00030-X

Nakamura, S.; Tanaka, H.; Kato, K. 2009. Static analysis of cable-stayed bridge with CFT arch ribs, Journal of Constructional Steel Research 65(4): 776-783. http://dx.doi.org/10.1016/j.jcsr.2008.05.005 
Park, S.; Kim, T.; Kim, K.; Hong, S.-N. 2010. Flexural behavior of steel I-beam prestressed with externally unbounded tendons, Journal of Constructional Steel Research 66(1): 125-132. http://dx.doi.org/10.1016/j.jcsr.2009.07.013

Rohde-Babarigos, L.; Nizar Bel Hadj Ali; Motro, R.; Smith, I. 2010. Designing tensegrity modules for pedestrian bridges, Engineering Structures 12: 1158-1167. http://dx.doi.org/10.1016/j.engstruct.2009.12.042

Ruiz-Teran, A. M.; Aparicio, A. C. 2007a. Two new types of bridges: under-deck cable-stayed bridges and combined cable-stayed bridges-the state of the art, Canadian Journal of Civil Engineering 34(8): 1003-1015. http://dx.doi.org/10.1139/107-017

Ruiz-Teran, A. M.; Aparicio, A. C. 2007b. Parameters governing the response of under-deck cable-stayed bridges, Canadian Journal of Civil Engineering 34: 10161024. http://dx.doi.org/10.1139/107-016

Ruiz-Teran, A. M.; Aparicio, A. C. 2008. Structural behavior and design criteria of under-deck cable-stayed bridges and combined cable-stayed bridges. Part 1: Single-span bridges, Canadian Journal of Civil Engineering 35: 938950. http://dx.doi.org/10.1139/L08-033

Ruiz-Teran, A. M.; Aparicio, A. C. 2011. Non-linear behaviour of under-deck cable-stayed, in Proc. of $V$ Congreso de $A C H E$. November, 2011. Barcelona, Spain. Bridge Technologies S. L. Available from Internet: http://www.bridgetechnologies.es/en/index.php?option $=\mathrm{c}$ om_k2\&view=item\&id=152:nonlinear-behaviour-ofunder-deck-cable-stayed-bridges\&Itemid $=4$

Ruiz-Teran, A. M.; Aparicio, A. C. 2010. Developments in under-deck and combined cable-stayed bridges. Proceedings of the Institution of Civil Engineers, Bridge Engineering 163 (June 2010, BE2): 67-78.
Sandovič, G.; Juozapaitis, A.; Kliukas, R. 2011. Simplified engineering method of suspension two-span pedestrian steel bridges with flexible and rigid cables under action of asymmetrical loads, The Baltic Journal of Road and Bridge Engineering 6(4): 267-273. http://dx.doi.org/10.3846/bjrbe.2011.34

Strasky, J. 2005. Stress-Ribbon and Supported Cable Pedestrian Bridges. London: Thomas Telford Ltd. 240 p. http://dx.doi.org/10.1680/sracspb.32828

Umezu, K.; Fujita, M.; Yamazaki, J. 1998. Study of a new structural type for prestressed concrete bridges. In LongSpan and High-Rise Structures, in Proc. of the IABSE Symposium, Kobe, Japan: Selected papers, vol. 79, International Association of Bridge and Structural Engineering (IABSE). September 1998, Zurich, 483-488.

Tanaka, T.; Yoshimura, T.; Gimsing, N. J.; Mizuta, Y.; Kang, W.-H.; Sudo, M.; Shinohara, T.; Harada, T. 2002. A study on improving the design of hybrid stress-ribbon bridges and their aerodynamic stability, Journal of Wind Engineering and Industrial Aerodynamics 90(12-15): 1995-2006. http://dx.doi.org/10.1016/S0167-6105(02)00316-1

Troyano, L. F. 2003. Bridge Engineering: A Global Perspective. London: Tomas Telford Ltd. 775 p.

Virlogeux, M. 1999. Recent evolution of cable-stayed bridges, Engineering Structures 21(8): 737-755. http://dx.doi.org/10.1016/S0141-0296(98)00028-5

Zhang, N.; Fu, Ch. 2009. Experimental and theoretical studies on composite steel concrete box beams with external tendons, Engineering Structures 31(2): 275-283. http://dx.doi.org/10.1016/j.engstruct.2008.08.004

Xue, W.; Liu, S. 2009. Design optimization and experimental study on beam string structures, Journal of Constructional Steel Research 65(1): 70-80. http://dx.doi.org/10.1016/j.jcsr.2008.08.009

Ieva MISIŪNAITÉ. Research assistant, PhD student at the Department of Bridges and Special Structures, Vilnius Gediminas Technical University, Lithuania. She has a Master of Science in Civil Engineering. Her main research areas include Steel Structures, Cable supported Bridge Structures, Beam-string Structures, Non-linear Buckling Analysis and Stability.

\begin{abstract}
Alfonsas DANIŪNAS. Dr, Assoc. Professor of Steel and Timber Structures Department, Vilnius Gediminas Technical University, Lithuania. He is an author and co-author of over than 150 articles in science and organisation of higher education. Research interests: analysis and optimization of elastic and plastic steel structures, numerical methods, i semi-rigid joints of steel structures.
\end{abstract}

Algirdas JUOZAPAITIS. Dr, Professor of Bridges and Special Structures Department, Vilnius Gediminas Technical University, Lithuania. He is an author and co-author of over than 60 scientific articles. His main research interests include Innovative Structural Systems of Steel Bridges and Special Structures, Geometrically Non-linear analysis and Stability of Steel Structures, Control of Internal forces in Steel Bridges and Special Structures. 